\title{
Effect of Nutrients Application Method on Productivity and Economics of Maize
}

\author{
Rama Kant Singh $^{1 *}$, Pankaj Kumar ${ }^{1}$, S.K. Singh ${ }^{1}$, Ajit Kumar Singh ${ }^{2}$ and S.B. Singh ${ }^{3}$ \\ ${ }^{1}$ Krishi Vigyan Kendra, Katihar \\ ${ }^{2}$ Department of Agriculture Economics, SMMTD College, Ballia \\ ${ }^{3}$ Krishi Vigyan Kendra, Gya \\ (Bihar Agricultural University, Sabour, Bhagalpur), India
}

*Corresponding author

\section{Keywords}

Growth and yield attributes, Maize, Nutrient application method, Zinc

Article Info

Accepted:

12 April 2019

Available Online:

10 May 2019

\section{A B S T R A C T}

The concept of balanced fertilization with proper method at proper time paves the way for optimum profitability of farmers. Since most of the soils in Koshi region of Bihar are sandy clay in their textural class with medium to low in N, P, K and Zn. Due to that farmers of Koshi region applying nutrients unscientifically. Therefore, they enable to reap best harvest and to augment the profitability from this crop and hence an experiment was conducted at farmer fields of Katihar district by Krishi Vigyan Kendra, Katihar, (Bihar Agricultural University Sabour, Bhagalpur) during two consecutive years of 2015-16 and 2016-17 to study the effect of nutrients application method on productivity and economics of maize. The experiment was laid out in alluvial soil with three treatments and ten replications in RBD. The details of treatments was $\left\{\left(\mathrm{T}_{1}-\right.\right.$ Farmer Practices (60:0: 0:: N:P:K Basal + 50:40:20 N:P:K at 30 DAS+ $30 \mathrm{~kg} \mathrm{~N}$ at 60 DAS), $T_{2}-R D F(60: 60: 40:: \mathrm{N}: \mathrm{P}: \mathrm{K}$ Basal + $45 \mathrm{~kg} \mathrm{~N}$ at 30 DAS+45 kg N at 60 DAS), T3- RDF (60:60:40:25:: N:P:K:Zn Basal $+45 \mathrm{~kg} \mathrm{~N}$ at $30 \mathrm{DAS}+45 \mathrm{~kg} \mathrm{~N}$ at $60 \mathrm{DAS})\}$. Healthy and bold seeds of maize var. Pioneer 3522 were dibbled into the soil @ 1 seed hill ${ }^{-1}$ at a spacing of $60 \mathrm{~cm} \mathrm{X} 20 \mathrm{~cm}$. The growth and yield attributes of maize viz., plant height, plant diameter, leaf length, leaf width, cob length, no of cob per plant, no of grains per cob, kernel and stover yield were significantly influenced by different method of nutrient application. There was a progressive increase in the growth and yield attributes with each application methods of nutrients applied from $T_{1}$ to $T_{2}$ and further increase in growth attributes were noticed when the graded levels fertility were supplemented with $\mathrm{Zn}$ as soil application $\mathrm{T}_{3}$. There was a gradual and progressive increase in growth and yield attributes with basal application of $\mathrm{P}$ $\mathrm{K}$ and zinc in comparison to $\mathrm{T}_{1}$ where $\mathrm{P} \mathrm{K}$ applied at 30 days after sowing.

\section{Introduction}

Maize is an important cereal in India, and both its area and production has been steadily increased over the past two decades. In India, the major maize growing season is kharif which accounts for about $85 \%$ of the total maize area. However, in spite of maximum 
share in area, the relative contribution of kharif maize is comparatively much lower than rabi maize. Rabi maize contributes more than $25 \%$ to annual production with less than $10 \%$ of total maize growing area. Several factors have been found to affect the productivity of rabi maize however; fertilizer management is one of the chief factors that affect the growth and yield of maize.

Maize is an exhaustive crop which requires adequate amounts of macro and micro nutrients in order to get better growth and exploit yield potential. Winter maize was proved to be more responsive to the fertilizer application (Savita Mehta et al., 2011) due to its vigorous plant growth and longer duration.

NPK are critical input in agriculture and its importance on account of the vital role being played in major life processes and its availability to the growing crop in required levels is of very important. Among the micro nutrients, zinc is now been reported as the fourth most important limiting nutrient element in the crop production after $\mathrm{N}, \mathrm{P}$ and $\mathrm{K}$. Under $\mathrm{Zn}$ deficiency conditions, flowering and yields are reduced and growth period is prolonged resulting in delayed maturity and quality of the crop may also suffer. Since most of the soils in Koshi region of Bihar are sandy clay in their textural class with medium to low in $\mathrm{N}, \mathrm{P}$ and $\mathrm{K}$ the nutrient requirement of this crop, especially with respect to the major nutrients needs to be scientifically quantified in proper time but farmers of Koshi region not applied as a basal dose of nutrients specially $\mathrm{P}, \mathrm{K}$ and $\mathrm{Zn}$.

Therefore, they enable to reap best harvest and to augment the profitability from this crop and hence the present investigation was conducted by Krishi Vigyan Kendra, Katihar to study the effect of nutrients application method on productivity and economics of maize.

\section{Materials and Methods}

The experiment was conducted at farmer fields of Katihar district by Krishi Vigyan Kendra, Katihar, (Bihar Agricultural University Sabour, Bhagalpur) during two consecutive years of 2015-16 and 2016-17 to study the effect of nutrients application method on productivity and economics of maize. It lies between Latitude $25^{\prime} \mathrm{N}$ to $26^{\prime} \mathrm{N}$, Longitude $87^{\prime}$ to $88^{\prime} \mathrm{E}$ with an altitude of 32 $\mathrm{m}$ above MSL. The climate is sub-tropical and humid having mean maximum and minimum temperature between $42^{\circ} \mathrm{C}$ and $4^{\circ} \mathrm{C}$, respectively and the average annual rainfall of the district is about $1200 \mathrm{~mm}$. The experimental soils are non-calcareous light gray flood plain belongs to the Alluvial Tract lies between three major rivers Mahananda, Kosi and Ganga. The soil samples were collected from different farmer field before start the experiment and after harvesting of the crop in each year and at each sampling site and analyzed with standard method.

The experiment was laid out in RBD with three treatments and ten replications in $4.0 \mathrm{~m}$ $\mathrm{X} 2.5 \mathrm{~m}$ plot size with treatments was $\left\{\left(\mathrm{T}_{1-}\right.\right.$ Farmer Practices (60:0: 0:: N:P:K Basal + $50: 40: 20 \mathrm{~N}: \mathrm{P}: \mathrm{K}$ at $30 \mathrm{DAS}+30 \mathrm{~kg} \mathrm{~N}$ at 60 DAS), $\mathrm{T}_{2}-\mathrm{RDF}$ (Basal 60:60:40:: N:P:K + 45 $\mathrm{kg} \mathrm{N}$ at $30 \mathrm{DAS}+45 \mathrm{~kg} \mathrm{~N}$ at $60 \mathrm{DAS}), \mathrm{T}_{3}-$ RDF (Basal 60:60:40:25:: N:P:K:Zn + 45 kg $\mathrm{N}$ at $30 \mathrm{DAS}+45 \mathrm{~kg} \mathrm{~N}$ at $60 \mathrm{DAS})\}$ respectively. Healthy and bold seeds of maize var. Pioneer 3522 were dibbled into the soil @ 1 seeds hill $^{-1}$ at a spacing of $60 \mathrm{~cm} \mathrm{X} 20$ cm i.e. plants density was 8300 plants ha $^{-1}$. The crop was harvested at maturity when the cobs dried and the entire plants turned yellow and analyzed standard statistical analysis of variance technique. The $\mathrm{B} \mathrm{C}$ ratio and other calculation done as follows:

Harvest index $=$ Economic yield (seed yield) Biological yield (seed + stover yields) 
Nutrient uptake by grain $\left(\mathrm{kg} \mathrm{ha}^{-1}\right)=$

Nutrient content $(\%)$ X Kernel yield $\left(\mathrm{kg} \mathrm{ha}^{-1}\right)$ 100

Nutrient uptake by stover $\left(\mathrm{kg} \mathrm{ha}^{-1}\right)=$

Nutrient content (\%) X Stover yield $\left(\mathrm{kg} \mathrm{ha}^{-1}\right)$ 100

Net returns $=$ Gross returns - Total operational cost $\left(\right.$ Rs. ha $\left.{ }^{-1}\right)$

B:C Ratio $=$ Net returns $\left(\right.$ Rs.ha $\left.{ }^{-1}\right)$ Cost of cultivation $\left(\right.$ Rs.ha $\left.^{-1}\right)$

\section{Results and Discussion}

\section{Effect of treatments on growth attributes of maize}

The growth parameters of maize viz., plant height, plant diameter, length and width of leaves gradually increased with the advancement in the growth intervals of the crop till the final stage under all treatments. The rate of increase in plant height was most rapid during 30 to 60 DAS. The full height was attained by the plants at 90 DAS and thereafter the plant height was almost ceased or decreased at harvest. Plant growth attributes significantly affected by various treatments at all the growth intervals of maize. Plant height, plant diameter, leaf length and leaf width were at harvesting stage maximum $(184.25 \mathrm{~cm}, 14.72 \mathrm{~cm}, 74.65 \mathrm{~cm}$ and $11.21 \mathrm{~cm}$ ) under $\mathrm{T}_{3}-\mathrm{RDF}$ (Basal 60:60:40:25:: N:P:K:Zn + $45 \mathrm{~kg} \mathrm{~N}$ at 30 DAS $+45 \mathrm{~kg} \mathrm{~N}$ at $60 \mathrm{DAS}$ ) which was significantly superior $(182.64,12.45,74.28$ and $10.73 \mathrm{~cm})$ over $\mathrm{T}_{2}-\mathrm{RDF}$ (Basal 60:60:40:: N:P:K + 45 $\mathrm{kg} \mathrm{N}$ at $30 \mathrm{DAS}+45 \mathrm{~kg} \mathrm{~N}$ at $60 \mathrm{DAS})$, While minimum (160.30, 11.34, 68.52 and 10.27 $\mathrm{cm})$ growth attributes were recorded under $\mathrm{T}_{1}-$ where 60:0: 0:: N:P:K Basal + 50:40:20 $\mathrm{N}: \mathrm{P}: \mathrm{K}$ at $30 \mathrm{DAS}+30 \mathrm{~kg} \mathrm{~N}$ at $60 \mathrm{DAS}$, respectively. It is possible due to reduced loss of nutrients from Indiscriminant doses of nutrients. Similar findings were also supported by Singh et al., (1995) and Chandrasekhar (2000) (Fig. 1).

\section{Effect of different treatments on yield parameters of maize}

The significant increase in yield attributes were observed under the application of different treatments viz. number of cob per plant, cob weight $(\mathrm{g})$, cob length, cob girth and number of grain row per cob (Table 3 and 4). This might be due to the sufficient amount of nutrient availability for the better growth and development of the plant which ultimately resulted in the higher yield attributes. Secondly the increase yield attributing characters might be due to rapid mineralization of $\mathrm{N}$ from organics which might have met the $\mathrm{N}$ requirement of the crop at critical stages. Organic act as nutrient reservoir and upon decomposition produce organic acid, thereby absorbed ion were released slowly during entire growth period leading to higher yield attributing characters. These findings are in agreement with those of Kumar and Singh (1992), Rameshwar et al., (1998), Sheeba et al., (2000) and Kumar and Singh (1992).

\section{Effect of different treatments on kernel and stover yield of maize}

Enhanced levels of nutrient supply exerted a significant and positive influence on the kernel yield of maize (Table 3 and Fig. 2). The kernel yield increased progressively with apply of fertiliser with $\mathrm{T}_{2}$ (60:60:40:: N:P:K basal $+45 \mathrm{~kg} \mathrm{~N}$ at $30 \mathrm{DAS}+45 \mathrm{~kg} \mathrm{~N}$ at 60 DAS) $92.32 \mathrm{qt} \mathrm{ha}^{-1}$ and the kernel yield was further escalated when these levels were supplemented with $\mathrm{Zn}$ through soil $\left(\mathrm{T}_{3}\right.$ 102.34 qt ha ${ }^{-1}$ ) 60:60:40:25:: N:P:K:Zn basal $+45 \mathrm{~kg} \mathrm{~N}$ at $30 \mathrm{DAS}+45 \mathrm{~kg} \mathrm{~N}$ at $60 \mathrm{DAS}$ in 
comparison with $\mathrm{T}_{1}\left(65.45 \mathrm{qt} \mathrm{ha}^{-1}\right)$ where nutrients supplied in unscientific manner 60:0: 0:: N:P:K as basal + 50:40:20 N:P:K at $30 \mathrm{DAS}+30 \mathrm{~kg} \mathrm{~N}$ at $60 \mathrm{DAS}$. In the present investigation the grain and stover yields were significantly more under highest concentration of Zn with RDF (Table 4). As the grain yield is positively correlated with yield attributes, which were also higher (Table 4 and 3) due to the more availability of nutrients under the application of $25 \mathrm{~kg} \mathrm{Zn} \mathrm{+}$ RDF application at critical stages, which ultimately produced the higher yields. These findings are in agreement with those of Singh et al., (1981), Hussen and Reddy (1985), Ramana et al., (2002) and Motavalli et al., (1993).

\section{Harvest Index}

As regarded harvest index it was not influenced markedly due to different treatments (Table 4). The maximum harvest index was obtained under $T_{3}-60: 60: 40: 25:$ : $\mathrm{N}: \mathrm{P}: \mathrm{K}: Z n$ basal $+45 \mathrm{~kg} \mathrm{~N}$ at $30 \mathrm{DAS}+45 \mathrm{~kg}$
$\mathrm{N}$ at 60 DAS $(0.58)$ which was close to $\mathrm{T}_{2}-$ 60:60:40:: N:P:K basal $+45 \mathrm{~kg} \mathrm{~N}$ at 30 DAS+45 $\mathrm{kg} \mathrm{N}$ at 60 DAS $(0.56)$ and $\mathrm{T}_{1}-$ 60:0: 0:: N:P:K as basal + 50:40:20 N:P:K at $30 \mathrm{DAS}+30 \mathrm{~kg} \mathrm{~N}$ at $60 \mathrm{DAS}(0.52)$. It is possible due to excellent growth and development of maize plant under higher nutrient environment during critical period of crop growth and highly correlated with the findings of Singh et al., (1995).

\section{Effect on soil properties}

Chemical properties of soil viz., $\mathrm{pH}, \mathrm{EC}, \mathrm{OC}$, and available $\mathrm{N}, \mathrm{P}$ and $\mathrm{K}$ status were determined before sowing and after harvest of crop under different treatments (Table 1) indicated that the different treatments did not altered the various properties of soil significantly. Since the present study concerned with the effect of RDF an application method with $\mathrm{Zn}$ on maize in experimental field only for two season, hence remarkable changes in soil properties was not observed.

Table.1 Effect of different treatments on physico-chemical properties of experimental soil

\begin{tabular}{|c|c|c|c|c|c|c|c|c|c|c|c|c|c|c|}
\hline \multirow[t]{3}{*}{ Treatments } & \multirow{2}{*}{\multicolumn{2}{|c|}{$\begin{array}{c}\text { pH } \\
(1: 2.5)\end{array}$}} & \multirow{2}{*}{\multicolumn{2}{|c|}{$\begin{array}{c}\text { ECe } \\
\left(\mathrm{d} \mathrm{Sm}^{-1}\right)\end{array}$}} & \multirow{2}{*}{\multicolumn{2}{|c|}{$\begin{array}{l}\text { OC } \\
(\%)\end{array}$}} & \multicolumn{2}{|c|}{$\mathbf{N}$} & \multicolumn{2}{|c|}{$\mathbf{P}$} & \multicolumn{2}{|c|}{$\mathbf{K}$} & \multirow{2}{*}{\multicolumn{2}{|c|}{$\begin{array}{c}\text { Zn } \\
\text { (ppm) }\end{array}$}} \\
\hline & & & & & & & \multicolumn{6}{|c|}{ Available Nutrients $\left(\mathrm{Kg} \mathrm{ha}^{-1}\right)$} & & \\
\hline & Initial & Final & Initial & Final & Initial & Final & Initial & Final & Initial & Final & Initial & Final & Initial & Final \\
\hline $\mathbf{T}_{1}$ & 6.92 & 6.83 & 0.19 & 0.21 & 0.26 & 0.26 & 189 & 180 & 22 & 19 & 235 & 232 & 0.42 & 0.40 \\
\hline $\mathbf{T}_{2}$ & 6.94 & 6.82 & 0.19 & 0.23 & 0.31 & 0.32 & 204 & 208 & 22 & 25 & 238 & 240 & 0.42 & 0.42 \\
\hline $\mathbf{T}_{3}$ & 6.95 & 6.88 & 0.21 & 0.30 & 0.33 & 0.35 & 215 & 224 & 23 & 27 & 241 & 248 & 0.45 & 0.48 \\
\hline$C D(p=0.05)$ & 0.02 & 0.02 & NS & 0.02 & 0.02 & 0.03 & 4.0 & 3.8 & 0.06 & 0.05 & 2.2 & 2.5 & NS & 0.2 \\
\hline
\end{tabular}

Table.2 Effect of different treatments on uptake of different nutrients in seed and stover of maize

\begin{tabular}{|c|c|c|c|c|c|c|}
\hline \multirow[t]{2}{*}{ Treatments } & \multicolumn{3}{|c|}{ Seed $\left(\mathrm{Kgha}^{-1}\right)$} & \multicolumn{3}{|c|}{ Stover $\left(\mathrm{Kgha}^{-1}\right)$} \\
\hline & $\mathbf{N}$ & $\mathbf{P}$ & $\mathbf{K}$ & $\mathbf{N}$ & $\mathbf{P}$ & $\mathbf{K}$ \\
\hline $\mathbf{T}_{1}$ & 27.21 & 6.25 & 24.45 & 164.74 & 52.38 & 240.51 \\
\hline $\mathbf{T}_{2}$ & 31.42 & 6.54 & 27.39 & 167.36 & 57.35 & 252.25 \\
\hline $\mathbf{T}_{3}$ & 33.55 & 7.28 & 31.50 & 170.22 & 61.62 & 255.30 \\
\hline $\mathrm{CD}(\mathrm{p}=0.05)$ & 0.74 & 0.04 & 0.25 & 1.04 & 0.95 & 2.08 \\
\hline
\end{tabular}


Table.3 Effect of different treatments on growth attributes of maize

\begin{tabular}{|l|l|l|l|l|l|l|l|l|}
\hline Treatment & $\begin{array}{l}\text { Plant } \\
\text { height } \\
\text { (cm) }\end{array}$ & $\begin{array}{l}\text { Plant } \\
\text { diameter } \\
\text { (cm) }\end{array}$ & $\begin{array}{l}\text { Leaf } \\
\text { length } \\
\text { (cm) }\end{array}$ & $\begin{array}{l}\text { Leaf } \\
\text { width } \\
\text { (cm) }\end{array}$ & $\begin{array}{l}\text { Cob } \\
\text { length } \\
\text { (cm) }\end{array}$ & $\begin{array}{l}\text { Cob } \\
\text { grith } \\
\text { (cm) }\end{array}$ & $\begin{array}{l}\text { No of } \\
\text { cob } \\
\text { plant }^{-1}\end{array}$ & $\begin{array}{l}\text { No of } \\
\text { grains } \\
\text { cob }^{-1}\end{array}$ \\
\hline $\mathbf{T}_{\mathbf{1}}$ & 160.30 & 11.34 & 68.52 & 10.27 & 14.76 & 11.2 & 1.35 & 342 \\
\hline $\mathbf{T}_{\mathbf{2}}$ & 182.64 & 12.45 & 74.28 & 10.73 & 16.31 & 14.8 & 1.38 & 365 \\
\hline $\mathbf{T}_{\mathbf{3}}$ & 184.25 & 14.72 & 74.65 & 11.21 & 16.87 & 16.5 & 1.39 & 387 \\
\hline $\mathbf{C D}(\mathbf{p}=\mathbf{0 . 0 5})$ & 1.54 & 1.21 & 0.26 & 0.22 & 0.05 & 0.78 & 0.02 & 4.56 \\
\hline
\end{tabular}

Table.4 Effect of different treatments on yield attributes of maize

\begin{tabular}{|c|c|c|c|c|c|c|c|}
\hline Treatment & $\begin{array}{l}\text { No of } \\
\text { grains } \\
\text { plant }^{-1}\end{array}$ & $\begin{array}{l}\text { Kernel wt } \\
\text { plant }^{-1}(\mathrm{~g})\end{array}$ & $\begin{array}{l}\text { Stove } \\
\text { wt. } \\
\text { plant } \\
1 \text { (g) }\end{array}$ & $\begin{array}{l}\text { Test wt } \\
1000 \\
\text { seeds } \\
(\mathrm{g})\end{array}$ & $\begin{array}{l}\text { Grain } \\
\text { yield (qt } \\
\text { ha }^{-1} \text { ) }\end{array}$ & $\begin{array}{l}\text { Stove } \\
\text { yield } \\
(\mathbf{q t} \\
\left.\mathbf{h a}^{-1}\right)\end{array}$ & $\begin{array}{l}\text { Harvesting } \\
\text { Index }\end{array}$ \\
\hline$T_{1}$ & 461.70 & 108.04 & 147.24 & 234 & 65.45 & 125.25 & 0.52 \\
\hline$T_{2}$ & 503.70 & 134.99 & 161.45 & 268 & 92.32 & 165.60 & 0.56 \\
\hline $\mathbf{T}_{3}$ & 537.93 & 153.31 & 175.63 & 285 & 102.34 & 175.16 & 0.58 \\
\hline $\mathrm{CD}(\mathrm{p}=0.05)$ & 12.61 & 15.85 & 8.24 & 14.70 & 11.45 & 9.36 & 0.01 \\
\hline
\end{tabular}

Table.5 Effect of different treatments on economics of maize

\begin{tabular}{|l|r|r|r|r|}
\hline Treatment & $\begin{array}{r}\text { Cost of cultivation } \\
\left(\text { (ss ha }^{-\mathbf{1}}\right)\end{array}$ & $\begin{array}{c}\text { Gross Income } \\
\left(\mathbf{R s ~ h a}^{-\mathbf{1}}\right)\end{array}$ & $\begin{array}{r}\text { Net Income } \\
\left(\mathbf{R s ~ h a}^{-\mathbf{1}}\right)\end{array}$ & \multicolumn{1}{c|}{ BC } \\
\hline $\mathbf{T}_{\mathbf{1}}$ & 48206 & 123574 & 75368 & 1.56 \\
\hline $\mathbf{T}_{\mathbf{2}}$ & 48806 & 150650 & 101844 & 2.09 \\
\hline $\mathbf{T}_{\mathbf{3}}$ & 50840 & 169805 & 118965 & 2.34 \\
\hline $\mathbf{C D}(\mathbf{p}=\mathbf{0 . 0 5})$ & 44.53 & 32.85 & 38.50 & NA \\
\hline
\end{tabular}

Fig.1

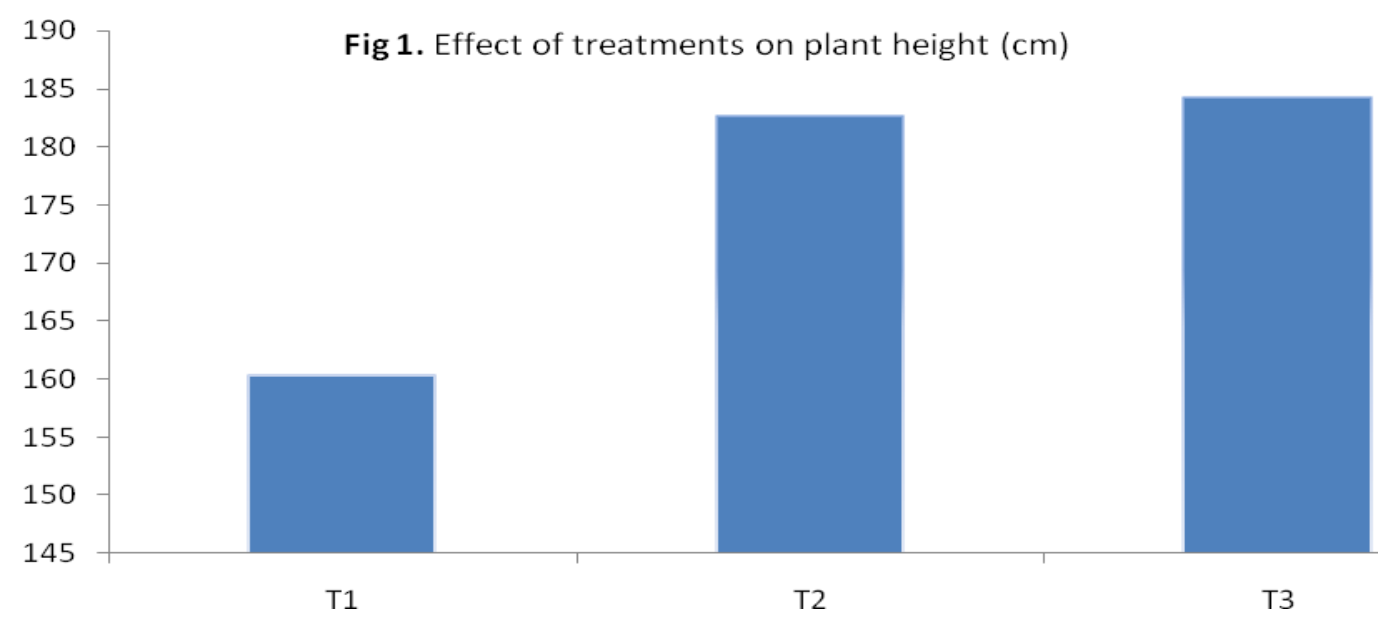


Fig.2

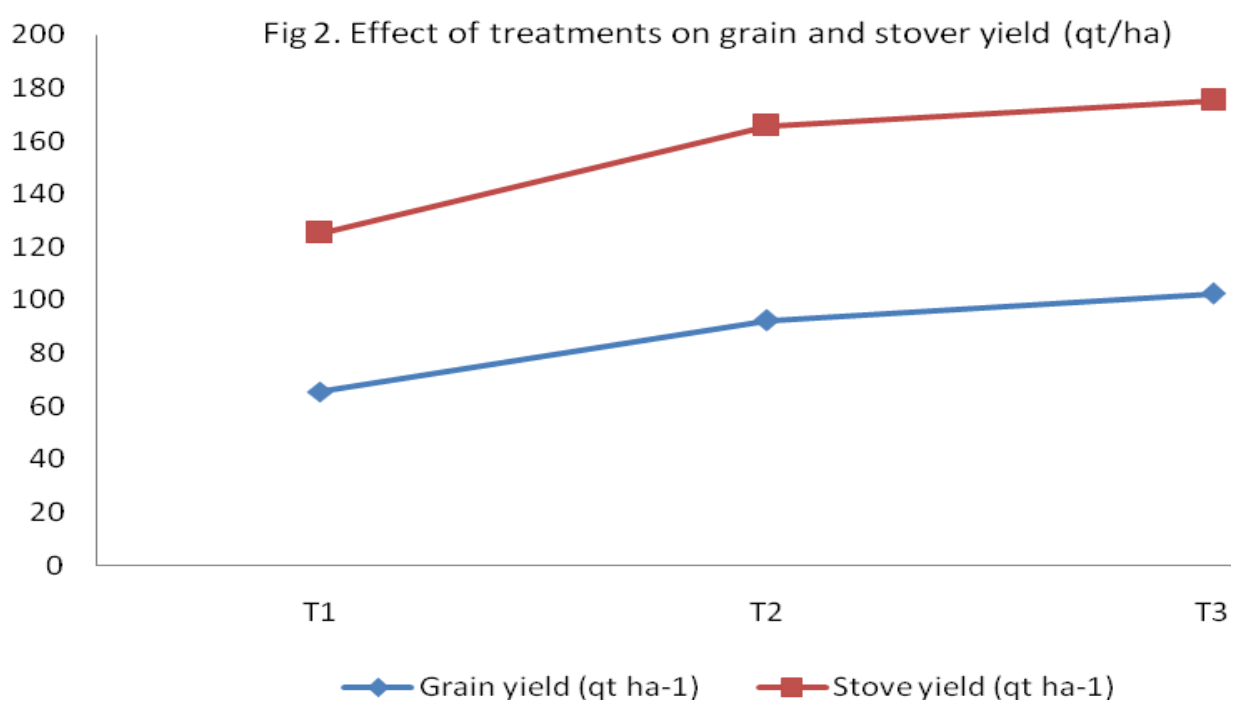

Fig.3

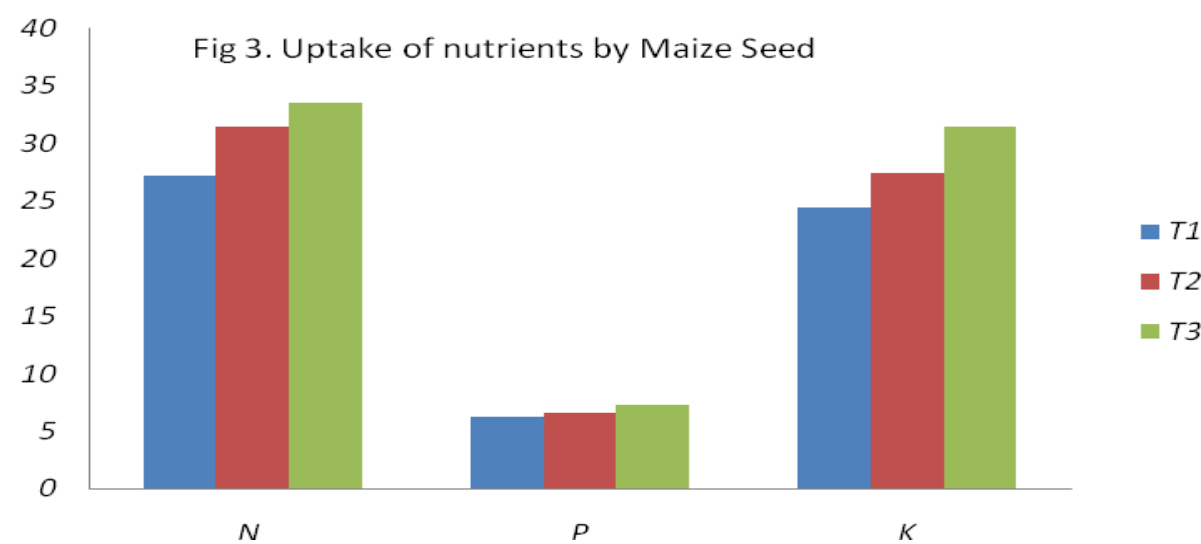

Fig.4

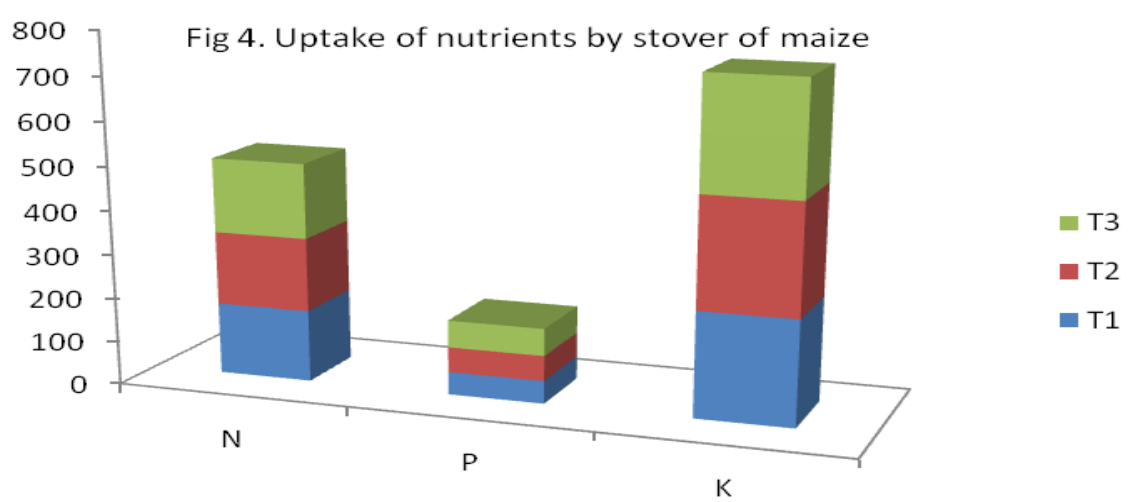


Fig.5

Fig 5. Effect of treatments on net income

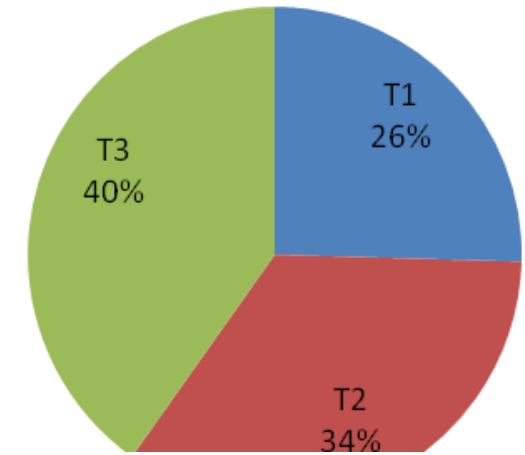

\section{Total N, P and K uptake by crop}

On considering the nutrients uptake in grain and stover (Table 2, Fig. $3 \& 4$ ) maximum N, P and $\mathrm{K}$ uptake in grain and stover were obtained under $T_{3}$ as compared to $T_{2}$ and $T_{1}$. The increase in nutrient contents and uptake could be attributed to increase supply of nutrients to the plant, which in turn might have resulted in profuse shoot and root growth thereby activating greater absorption of $\mathrm{N}, \mathrm{P}$ and $\mathrm{K}$ from the soil. These results were also supported by Prasad et al., (2010).

\section{Effect of different treatments on economics of maize}

The economic analysis of the treatment is the most important from the farmer's point of view regarding implementation of the practices evolved under any investigation. Economic analysis of treatment was determined on per hectare area basis, which includes cost of cultivation, gross monetary returns, net monetary returns and benefit cost ratio as affected by various treatments (Fig. 5 and Table $5)$. The cost of cultivation was noted minimum under $\mathrm{T}_{1}$ and it increased orderly with different treatments due to increase in addition of application method with $\mathrm{Zn}$. The higher gross income were observed under $\mathrm{T}_{3}$ due to obtaining higher grain and stover yields with these treatments. The maximum $\mathrm{B}: \mathrm{C}$ ratio was noticed under the application of nutrients as 60:60:40:25:: N:P:K:Zn basal $+45 \mathrm{~kg} \mathrm{~N}$ at 30
DAS $+45 \mathrm{~kg} \mathrm{~N}$ at $60 \mathrm{DAS}$ (2.34) thus indicate that for achieving the maximum benefit. The maximum benefit per rupee investment might be due to the application of nutrients in three split as one third $\mathrm{N}$ with full doses of $\mathrm{P}$ and $\mathrm{K}$ with $25 \mathrm{~kg} \mathrm{Zn}$ as compared to other treatments.

\section{References}

Aruna M., Veeraraghavaiah R. and Chandrasekhar K. 2006. Productivity and quality of maize (Zea mays L) as affected by foliar application of $\mathrm{N}$ and $\mathrm{Zn}$ at flowering. The Andhra Agricultural Journal. 53(1\&2): 17-19.

Chandrashekar. 2000. Response of maize (Zea mays L.) to organic manures with inorganic fertilizers. Karnataka Journal of Agril. Science, 13(1): 144-146

Chopra C. L. and Kanwar J. S. 1991 Analytical Agricultural Chemistry, Kalyani Publication, New Delhi.

Husssen M. and Reddy D.B. 1985. Studies on yield response of hybrid maize to level of $\mathrm{N}$ and $\mathrm{P}_{2} \mathrm{O}_{5}$. Indian J. Agron. 30: 384385.

Jackson M. C. 1973. Soil chemical analysis, prentice hall of India private limited, New Delhi, pp.498.

Kumar Anil S., Chidanandappa H.M and Babu Vijay Sankar M. 2010. Effect of different souces of zinc of growth, yield and uptake of nutrient by maize crop (Zea mays L.). Mysore Journal of Agricultural Sciences. 44 (1): $92-99$. 
Kumar S. and Singh R.P. 1992. Cob characteristic and soybean yield in maize - legume inter cropping system, Himachal J. of Agron. 8(1): 38-43.

Manimaran M. and Poonkodi P. 2009. Yield and yield attributes of maize as influenced by graded levels of phosphorous fertilization in salt affected soils. Annals of Agricultural research. 30(1\&2): 26-28.

Motavalli P.P., Kelling K.A., Synerud T.D. and Wolkowski R.P. 1993. Interaction of manure fertilizers in northern crop production. Journal of production Agriculture, 6(2): 192-194.

Olsen S. R., Cole C. L., Watnab P.S and Dean L. A. 1954. Estimation of available phosphorous in soils by extraction with sodium bicarbonates, USDA Circular No. 939.

Prasad J., Karmakar S., Kumar R. and Mishra B. 2010 Influence of Integrated Nutrient Management on Yield and Soil Properties in Maize-Wheat Cropping System in an Alfisol of Jharkhand. Journal of the Indian Society of Soil Science, 58 (2): 200-204.

Ramana S., Biswas A.K. and Singh K.K. 2002. Effect of distillery effluents on some physiological aspects in maize. Bioresource Technology 84(3): 295-297

Rameshwar and Singh C.M. 1998. Nutrient many for yield maximization in maize (Zea mays)- Wheat system under rainfed mid hilly condition of H.P. Himachal J. of Agricultural Research, 24 (1-2): 11-19

Rameshwar, Singh C.M., Sharma S. and Singh G. 2001. Crop yields and soil fertility under different combinations of fertilizers and FYM in maize-wheat sequence under rainfed conditions. Journal hill research,
14(1): 26-31.

Reddy Y.V.R., Somani L.L. and Rama Krishna Y.S. 2008. Maize production technology. Agro Publishing Academy, Vinayaka complex, Udaipur. P - 31-49.

Sheeba S. and Chellamuthu S. 2000. Effect of long term application of fertilizers and manure on soil properties and yield under maize- cowpea-ragi rotation. Journal of Eco-physiology 3(3): 117-121.

Singh A., Vyas A. K. and Singh A.K. 1995 Effect of Nitrogen and Zine application on growth, yield and net return of maize. Annual Agricultural Research, 21(2): 296-297

Singh A., Awasthi R.P., Singh R.D. and Arya R.L. 1995. Effect of inorganic fertilizer in maize (Zea Mays) and ginger intercropping system in humid hilly soils. Indian Journal of Agronomy, 40(4): 549552.

Singh D. and Singh S.M. 2006. Response of early maturing maize (Zea mays) hybrids to applied nutrients and plant densities under agroclimatic conditions of Udaipur in Rajasthan. Indian Journal of Agricultural Sciences. 76 (6): 372 - 374.

Subbiah B.V. and Asija G.L. 1956 b. Alkaline Permanganate Method. Current Science. 25: 255 - 260.

Tandon H.L.S. 1999. Methods of analysis of soil, plants, waters and fertilizers. Fertilizer Development and Consultation Organisation, New Delhi. P- 63.

Walkley A. and Black C.A. 1934. An examination of determining soil organic carbon and proposed modification of the chromic acid titration method. Soil Science. 37: 29-34.

\section{How to cite this article:}

Rama Kant Singh, Pankaj Kumar, S.K. Singh, Ajit Kumar Singh and Singh, S.B. 2019. Effect of Nutrients Application Method on Productivity and Economics of Maize. Int.J.Curr.Microbiol.App.Sci. 8(05): 1443-1450. doi: https://doi.org/10.20546/ijcmas.2019.805.165 